Zagazig J. Agric. Res., Vol. 46 No. (6A) 2019

Plant Production Science

http:/www.journals.zu.edu.eg/journalDisplay.aspx?Journalld=1\&queryType=Master

\title{
RESPONSE OF SOME TOMATO HYBRIDS TO DIFFERENT FERTILIZATION SOURCES UNDER HIGH TEMPERATURE CONDITIONS
}

\author{
Ahmed A. Moustafa, M.H. El-Sawah and M.H. Arisha* \\ Hort. Dept., Fac. Agric., Zagazig Univ., Egypt \\ Received: 09/05/2019; Accepted: 18/08/2019
}

\begin{abstract}
This work was carried out in a Private Farm at Awlad Saqr District, Sharkia Governorate, Egypt during two successive summer seasons of 2016 and 2017 to study the effect of mineral fertilizers (NPK), organic fertilizer in the form of poultry manure (PM) and bio-fertilizer (Nitrobein, Phosphorein and Potassiumag) each alone and their mixture on dry weight parameters, flowering, fruit set and yield and its components of some tomato hybrids grown under high temperature conditions. The experimental design was split plots with three replicates included 14 treatments. Two different tomato hybrids were used included. Alia123 $\left(\mathrm{V}_{1}\right)$ and Rama888 $\left(\mathrm{V}_{2}\right)$ were randomly distributed in the main plots and 7 fertilization treatments [100\%mineral fertilizers $\left(\mathrm{T}_{1}\right)$, $100 \%$ bio-fertilizers $\left(\mathrm{T}_{2}\right), 100 \%$ organic $\left(\mathrm{T}_{3}\right), 100 \%$ mineral $+100 \%$ organic manure $+100 \%$ biofertilizer $\left(\mathrm{T}_{4}\right), 75 \%$ mineral $+100 \%$ organic manure $+100 \%$ bio-fertilizer $\left(\mathrm{T}_{5}\right), 50 \%$ mineral $+100 \%$ organic manure $+100 \%$ bio-fertilizer $\left(\mathrm{T}_{6}\right)$ and $25 \%$ mineral $+100 \%$ organic manure $+100 \%$ biofertilizer $\left(\mathrm{T}_{7}\right)$ ] were arranged in sub plots. Results showed that dry weight of shoots per plant and total dry in Alia123 $\left(\mathrm{V}_{1}\right)$ hybrid significantly increased. While Rama888 hybrid $\left(\mathrm{V}_{2}\right)$ significantly enhanced flowering, fruit set characters, as well as yield and its components. Moreover, $100 \%$ mineral $+100 \%$ organic manure $+100 \%$ bio-fertilizer $\left(\mathrm{T}_{4}\right)$ significantly improved all dry weight parameters. Also the same treatment significantly increased flowering, fruit set characters and yield and its components. Furthermore, using Alia123 $\left(\mathrm{V}_{1}\right)$ hybrid with mixture of $100 \%$ mineral $+100 \%$ organic fertilizer + $100 \%$ bio-fertilizer $\left(\mathrm{T}_{4}\right)$ significantly enhanced all dry weight parameters. While using Rama 888 hybrid $\left(\mathrm{V}_{2}\right)$ with a mixture of $100 \%$ mineral $+100 \%$ organic fertilizer $+100 \%$ bio-fertilizer $\left(\mathrm{T}_{4}\right)$ were the superior interaction treatment which reflected a significant effect on all flowering and fruit set characters, as well as yield and its components. Generally the both hybrids were recorded good results for sowing under high temperature conditions in most cases.
\end{abstract}

Key words: Tomato hybrids, bio-fertilizer, organic fertilizer, flowering, fruit set, yield, high temperature.

\section{INTRODUCTION}

Tomato (Solanum lycopersicum, Mill) belongs to family Solanaceae that considered as important vegetable crops all over the world. Its can be used as a fresh or paste in all parts of the world (Alofe and Somade, 1982). High temperature above the optimal degree of crop growth adversely affects vegetative growth and decreases productivity. The best temperature for growing tomato ranged between $21-24^{\circ} \mathrm{C}$, and increasing temperature higher than $28^{\circ} \mathrm{C}$ will gradually decreases the yield leading to death level at $35^{\circ} \mathrm{C}$ (Abdellatif et al., 2017). Tomato flowering optimal degree ranged between 15 $25^{\circ} \mathrm{C}$, while fruit set is between $18-20^{\circ} \mathrm{C}$ (DeKoning, 1994).

Balance fertilizations in tomato crop during all growth stages is necessary for satisfactory growth, development and also yield. Among different nutrients that are required for tomato cultivation, nitrogen, and phosphorus and potassium considered as the most important

\footnotetext{
*Corresponding author: Tel. : +201002399026

E-mail address: mohhamedarisha@gmail.com
} 


\section{Moustafa, et al.}

nutrients. Nitrogen influences the vegetative growth through its function of building up proteins which induces cell division and initial meristic activity. Phosphorus is essential for root development and utilization of water and other nutrients by tomato plants. Potassium serves as an enzyme activator, and assists in the transport of assimilated results from the leaf to the plant tissue (Jayaweera and Mikkelsen, 1991).

Nowadays, organic farming is one of the fastest growing sectors of agriculture all over the world. its goal is to create a balance between combined systems of soil organisms, plants, animals, as well as humans (Karanatsidis and Berova, 2009). Poultry manure is one of the best nutrients source for plants, enhanced the nutrients in the soil, required avoid nutrient imbalances and related animal health dangers, as well as surface and ground water contamination (Blay et al., 2002; Phan et al., 2002).

Bio-fertilizers enclose useful microorganisms in a viable state, dedicated to seed or soil application and intended to improve soil fertility. It helps plant in growth by increasing the number of desired bacteria and its biotic activity in the root environment (Subba, 1999). Moreover, biofertilizer directly enhance growth elevation by production of phytohormons, improving obtainability of nutrients, nonsymbiotic nitrogen fixation and enriching of diseases resistance mechanisms (Zdor and Anderson, 1992). Nitrogen fixing bacteria, such as Azospirillium braselence and Azotobacter chroccocum that fixing $\mathrm{N}$ and produce ammonia for their own use and support the plant with nitrogen, as an exchange carbon and protected habitat (Marschner, 1995). Phosphate dissolving bacteria, similar Bacillus megaterium that dissolve phosphorus from organic phosphorus complexes to make it soluble for the plant through the production of enzymes phosphate. As well as producing biotic compounds, such as hormones like auxin and gibberellic acid (Mehrvarz and Chaich, 2008). Potassium dissolving bacteria like, Bacillus circulans, that breakdown potassium from complex insoluble minerals into a simple form (Alexander, 1985).

Therefore, the aim of this work was to study the effect of mineral, organic and bio-fertilizers each alone and their combination along with using two different tomato hybrids on some growth parameters, flowering and fruit set well as yield and its components under high temperature conditions.

\section{MATERIALS AND METHODS}

This work was carried out in a Private Farm at Awlad Saqr District, Sharkia Governorate, Egypt during two successive summer seasons of 2016 and 2017 to evaluate the effectiveness of organic manure, bio-fertilizers and different levels of the mineral fertilizers each alone and their mixture on dry weight parameters, flowering, fruit set and yield with its components of some tomato hybrids grown under high temperature conditions in clay loam soil and flood irrigation system. Two different tomato (Solanum lycopersicum, Mill) hybrids were used in the experiment including Alia123 (Produced by Diamonds seeds Co. (Spain). Imported by Technogreen Co. for seeds, Egypt) hybrid $\left(\mathrm{V}_{1}\right)$ and Rama888 (Produced by Sun Rise seeds Co. (USA). Imported by Sand Valley comp. for agricultural development, Egypt) hybrid $\left(\mathrm{V}_{2}\right)$. Seedling of both tomato hybrids was brought from a Private nursery (El-Salhya El-Jaded City, , Sharkia Governorate Egypt). This experiment was carried out in a split plot design with three replicates including 14 treatments, which were combination of the two tomato hybrids with 7 fertilizer treatments as follows: $\left[100 \%\right.$ mineral fertilizers $\left(\mathrm{T}_{1}\right), 100 \%$ biofertilizers $\left(\mathrm{T}_{2}\right), 100 \%$ organic manure $\left(\mathrm{T}_{3}\right)$, $100 \%$ mineral $+100 \%$ organic manure $+100 \%$ bio-fertilizer $\left(\mathrm{T}_{4}\right), 75 \%$ mineral $+100 \%$ organic manure $+100 \%$ bio-fertilizer $\left(\mathrm{T}_{5}\right), 50 \%$ mineral $+100 \%$ organic manure $+100 \%$ bio-fertilizer $\left(\mathrm{T}_{6}\right)$ and $25 \%$ mineral $+100 \%$ organic manure $+100 \%$ bio-fertilizer $\left.\left(\mathrm{T}_{7}\right)\right]$. The two tomato hybrids were randomly distributed in the main plots and the fertilizer treatments were in the sub plots. The used mineral fertilizers were (NPK) in the form of ammonium nitrate $(33.5 \% \mathrm{~N})$, calcium superphosphate $\left(\begin{array}{lll}15.5 \% & \mathrm{P}_{2} \mathrm{O}_{5}\end{array}\right)$ and potassium sulfate $\left(48 \% \mathrm{~K}_{2} \mathrm{O}\right)$ were applied at $500 \mathrm{Kg} / \mathrm{fad}$., (1.6 kg/plot), $400 \mathrm{Kg} / \mathrm{fad}(1.3 \mathrm{~kg} /$ plot) and $250 \mathrm{Kg} / \mathrm{fad} .,(0.804 \mathrm{~kg} / \mathrm{plot})$ of the recommended dose, respectively. Bio-fertilizers were nitrobine (Azospirillium sp. + Azotobacter 
Zagazig J. Agric. Res., Vol. 46 No. (6A) 2019

sp., nitrogen fixing bacteria), phosphorein (Bacillus megatherium, phosphate dissolving bacteria) and potassiumag (Bacillus circulans, potassium dissolving bacteria) (were brought from Agriculture Research Centre (ARC), Giza Egypt). $1 \mathrm{~kg} / \mathrm{fad}$., $(3.5 \mathrm{~g} / \mathrm{plot})$ of each biofertilizer types in recommended doses were used one time at the beginning of the growing seasons by dissolving $3.5 \mathrm{~g} / \mathrm{plot}$ of each one in 3 liter water. Seedling roots of each plot which received bio-fertilizers were dipped in the dissolved bio-fertilizers for 5 minutes and then transplanted in the irrigated ridges directly and were added at $100 \%$ of the recommended dose.

Organic fertilizer was poultry manure (from a private poultry farm), which was added at 10.5 ton/fad., (33.75 kg/plot), as a recommended dose. The experiment site was plowed three times and calcium super phosphate was added at one time during preparing the ridges. Organic fertilizer was added to the plots in the same way of adding calcium super phosphate at $100 \%$ of the recommended dose. Seeds of the both tomato hybrids were sown in the private nursery on $8^{\text {th }}$ April and transplanted on $8^{\text {th }}$ May in the both growing seasons. The seedlings were transplanted at a distance of $40 \mathrm{~cm}$ apart. The plot area was $13.5 \mathrm{~m}^{2}$ (3 ridges with $3 \mathrm{~m}$ length and 1.5 widths). Ammonium nitrate and potassium sulfate were applied three times (first time at 30 days after transplanting and then added every 15 days, intervals). Both of them were well dissolved in 5.25 liter water and 250 $\mathrm{cm}^{3}$ add to every seedling at a distance of $5 \mathrm{~cm}$ from its root. Tomato plants were irrigated by flood irrigation 6 times per season. All experiment plots were received magnesium sulfate at $50 \mathrm{~kg} / \mathrm{fad}$., (161g/plot) which was added with the third time of adding mineral fertilizers, and foliar sprayed three times with micronutrients and amino acids at 10 days after transplanting then two times every 15 days, intervals. In addition, tomato plants were sprayed with fungal and insecticides, as well as foliar spraying two times with calcium boron during fruiting. Temperature of growing seasons obtained from Egyptian Meteorological Station, Sharkia Governorate was presented in Table 1. Data obtained as daily temperature and the average was recorded for each month separately.
This data was to know the effect of high temperature of both growing seasons (JuneAugust) on the efficiency of different fertilizers for tomato plants growth and yield.

\section{Studied Characters}

\section{Dry weight}

The different parts of three tomato plants, at 75 days after transplanting were oven dried at $70^{\circ} \mathrm{C}$ till constant weight, then recorded: leaves dry weight/plant (g), roots dry weight/plant (g), shoots dry weight/ plant ( $\mathrm{g}$ ) and total dry weight (leaves, roots and shoots)/plant (g).

\section{Flowering and fruit set}

A random sample of three plants was taken from each plot in 2017 season for measuring:

1. Number of flowers/plant at 60 days after transplanting.

2. Number and percentage of fruit set of known 20 flowers marked at 55 days after transplanting and were counted after 20 days. The air temperature of 20 days was recorded at 2 and 9 Post meridiem (pm) by using a digital thermometer. The average of 20 days was calculated too $\left(40.1 / 26.9^{\circ} \mathrm{C}\right.$ day/ night).

3. Number of fruits/cluster, number of fruit clusters/plant were determined at 75 days after transplanting.

\section{Yield and its components}

Fruits of each plot were harvested at full ripe maturity stage, and then counted, weighted and the following yield parameters were calculated: Number of fruits/plant, average fruit weight $(\mathrm{g})$, yield/plant $(\mathrm{kg}$ ), early yield (first and second picking ton/ fad.) and total yield (ton/fad.).

\section{Statistical Data Analyses}

All the obtained data during the growth seasons of the study were statistically analyzed using statistics 8.1 software program to find out the statistical significance of the experimental results of both seasons. The differences between means were compared using the least significant difference (LSD) test at the probability of 5\% level according the method described by Snedecor and Cochran (1980). 
Moustafa, et al.

Table 1. Recorded temperature $\left({ }^{\circ} \mathrm{C}\right)$ of the both growing seasons at Sharkia Government*

\begin{tabular}{lcccccc}
\hline Month & \multicolumn{3}{c}{ 2016 season } & \multicolumn{3}{c}{ 2017 season } \\
\cline { 2 - 7 } & Max. temp. ${ }^{\circ} \mathbf{C}$ & Min. temp. ${ }^{\circ} \mathbf{C}$ & Mean & Max. temp. ${ }^{\circ} \mathbf{C}$ & Min. temp. ${ }^{\circ} \mathbf{C}$ & Mean \\
\hline May & 36.2 & 24.4 & 30.3 & 37.6 & 25.1 & 30.85 \\
June & 37.8 & 25.4 & 31.6 & 39.2 & 26.3 & 32.75 \\
July & 39.6 & 25.6 & 32.6 & 40.2 & 27.4 & 33.8 \\
August & 36.4 & 24.1 & 30.25 & 38.3 & 26.4 & 32.35 \\
\hline
\end{tabular}

* Egyptian Meteorological Station (Cairo)

\section{RESULTS AND DISCUSSION}

\section{Dry Weight}

\section{Effect of tomato hybrids grown under high temperature conditions}

Results presented in Table 2 show the effect of hybrids on the dry weight of different parts of tomato plants grown under high temperature conditions, i.e., roots, shoots, leaves, as well as total dry weights per plant in 2016 and 2017 seasons. Its clear from the results in this table that the dry weight of both leaves and roots per plant were not significantly affected by the tested hybrids in both the studied seasons. On the other hand, dry weight of shoots per plant and total dry weight per plant significantly increased in Alia123 hybrid $\left(\mathrm{V}_{1}\right)$ than hybrid $\left(\mathrm{V}_{2}\right)$ in both studied seasons. The variations under high temperature might be due to the genetic variability between those hybrids as Alia 123 is heat resistant hybrid while, Rama 888 is a heat sensitive hybrid. This result was in consensus with Hossain et al. (2012) and Shamsuzzaman et al. (2017) on dry weight of tomato genotypes.

\section{Effect of different fertilization sources and its rates on the dry weight of tomato plants parts grown under high temperature conditions}

Results in Table 2 show the effect of different fertilization sources and its rates on the dry weight of different organs of tomato plant, as well as total dry weight per plant, grown under high temperature conditions during 2016 and 2017 season. It was obvious from the recorded results that, tomato plants fertilized with a mixture of $100 \%$ minerals $+100 \%$ organic fertilizer $+100 \%$ bio-fertilizer $\left(\mathrm{T}_{4}\right)$ significantly enhanced dry weight of leaves, shoots, as well as total dry weight per plant in the two studied seasons, except dry weight of roots which didn't reflect any significant effect between a mixture of $100 \%$ mineral $+100 \%$ organic fertilizer+ $100 \%$ bio-fertilizer $\left(\mathrm{T}_{4}\right)$ compared with $75 \%$ mineral $+100 \%$ organic fertilizer+ $100 \%$ bio-fertilizer $\left(\mathrm{T}_{5}\right)$ and $50 \%$ minerals $+100 \%$ organic fertilizer $+100 \%$ biofertilizer $\left(\mathrm{T}_{6}\right)$ in the first season and $100 \%$ minerals $+100 \%$ bio-fertilizer $+100 \%$ organic fertilizer $\left(\mathrm{T}_{4}\right)$ compared with $75 \%$ minerals $+100 \%$ bio-fertilizer $+100 \%$ organic fertilizer $\left(\mathrm{T}_{5}\right)$ in the second season, respectively. While $100 \%$ bio-fertilizer significantly gave the lowest dry weight of all plant parts. The previous results suggested that such enhanced might be due to the effect of NPK, where nitrogen is basic for photosynthesis, creation of chlorophyll and nucleic acids and its absence or deficiency causes stunted growth (Tisdale et al., 2003). Beside this, nitrogen is a necessary component of protoplasm and enzymes that the biological catalytic agents, which speed up the biological processes (Mengel and Kirkby, 1978). Also phosphorus is involved in cell metabolism and is vital for the biosynthesis of primary and secondary metabolites in plants (Habibzadeh and Moosavi, 2014). In addition, the $K$ component in the NPK fertilizer serves as an enzyme activator, and assists in the transport of assimilated produced from the leaf to the plant tissue (Jayaweera and Mikkelsen, 1991). Consequently, those elements have great role for enhancing plant growth. Abdelhady et al. (2017) and Mesallam et al. (2017) found that, mineral (NPK) fertilizer improved dry weight of tomato plants. Another reason, it might attribute 
Zagazig J. Agric. Res., Vol. 46 No. (6A) 2019

Table 2. Effect of hybrids and different fertilization sources on the dry weight parts of tomato plants grown under high temperature condition during 2016 and 2017 seasons.

\begin{tabular}{|c|c|c|c|c|c|c|c|c|}
\hline \multirow{3}{*}{$\begin{array}{l}\text { Tomato } \\
\text { hybrid }\end{array}$} & \multicolumn{8}{|c|}{ Dry weight/ plant (g) } \\
\hline & \multicolumn{4}{|c|}{2016 season } & \multicolumn{4}{|c|}{2017 season } \\
\hline & Leaves & Roots & Shoots & Total & Leaves & Roots & Shoots & Total \\
\hline & \multicolumn{8}{|c|}{ Effect of tomato hybrids } \\
\hline $\mathbf{V}_{1}$ & $51.214 \mathrm{a}$ & $12.166 \mathrm{a}$ & $58.431 \mathrm{a}$ & $121.67 \mathrm{a}$ & $53.350 \mathrm{a}$ & $12.435 \mathrm{a}$ & 58.962 a & $124.75 \mathrm{a}$ \\
\hline $\mathbf{V}_{2}$ & $51.669 \mathrm{a}$ & $11.770 \mathrm{a}$ & $47.805 \mathrm{~b}$ & $111.12 \mathrm{~b}$ & $53.191 \mathrm{a}$ & $11.251 \mathrm{a}$ & $50.466 \mathrm{~b}$ & $114.91 \mathrm{~b}$ \\
\hline & & & Effect & f different & ertilizatio & n sources & & \\
\hline \multicolumn{9}{|c|}{$\begin{array}{c}\text { Fertilization } \\
\text { treatments }\end{array}$} \\
\hline $\mathbf{T}_{1}$ & $55.920 \mathrm{c}$ & $12.388 \mathrm{ab}$ & $59.331 \mathrm{~b}$ & $127.64 \mathrm{~b}$ & $58.255 \mathrm{~b}$ & $11.211 \mathrm{c}$ & $61.194 \mathrm{~b}$ & $130.66 \mathrm{~b}$ \\
\hline $\mathbf{T}_{2}$ & $36.696 \mathrm{e}$ & $9.362 \mathrm{~d}$ & $39.138 \mathrm{e}$ & $85.20 \mathrm{e}$ & $42.038 \mathrm{e}$ & $8.660 \mathrm{~d}$ & $43.910 \mathrm{~d}$ & $94.61 \mathrm{e}$ \\
\hline $\mathbf{T}_{\mathbf{3}}$ & $44.438 \mathrm{~d}$ & $11.792 \mathrm{bc}$ & $44.900 \mathrm{~d}$ & $100.69 \mathrm{~d}$ & $51.481 \mathrm{c}$ & $11.853 \mathrm{c}$ & $51.758 \mathrm{c}$ & $115.09 \mathrm{c}$ \\
\hline $\mathbf{T}_{4}$ & $66.175 \mathrm{a}$ & $13.400 \mathrm{a}$ & $65.996 \mathrm{a}$ & $145.57 \mathrm{a}$ & $66.233 \mathrm{a}$ & $14.147 \mathrm{a}$ & $67.437 \mathrm{a}$ & $147.82 \mathrm{a}$ \\
\hline $\mathbf{T}_{5}$ & $58.776 \mathrm{~b}$ & $13.258 \mathrm{a}$ & $59.038 \mathrm{~b}$ & $130.57 \mathrm{~b}$ & $58.008 \mathrm{~b}$ & $3.252 \mathrm{ab}$ & $59.668 \mathrm{~b}$ & $130.93 \mathrm{~b}$ \\
\hline $\mathbf{T}_{6}$ & $53.513 \mathrm{c}$ & $12.582 \mathrm{ab}$ & $55.975 \mathrm{c}$ & $122.07 \mathrm{c}$ & $51.933 \mathrm{c}$ & $2.047 \mathrm{bc}$ & $53.325 \mathrm{c}$ & $117.31 \mathrm{c}$ \\
\hline $\mathbf{T}_{7}$ & $44.575 \mathrm{~d}$ & $10.992 \mathrm{c}$ & $47.446 \mathrm{~d}$ & $103.01 \mathrm{~d}$ & $44.945 \mathrm{~d}$ & $11.732 \mathrm{c}$ & $45.705 \mathrm{~d}$ & $102.38 \mathrm{~d}$ \\
\hline
\end{tabular}

$\mathrm{V}_{1}$ : Alia123 hybrid, $\mathrm{V}_{2}:$ Rama888 hybrid, $\mathrm{T}_{1}: 100 \%$ mineral fertilizers, $\mathrm{T}_{2}: 100 \%$ bio-fertilizers, $\mathrm{T}_{3}: 100 \%$ organic manure $\mathrm{T}_{4}: 100 \%$ mineral $+100 \%$ organic manure $+100 \%$ bio-fertilizer, $\mathrm{T}_{5}: 75 \%$ mineral $+100 \%$ organic manure $+100 \%$ bio-fertilizer, $\mathrm{T}_{6}: 50 \%$ mineral $+100 \%$ organic manure $+100 \%$ bio-fertilizer, $\mathrm{T}_{7}: 25 \%$ mineral $+100 \%$ organic manure $+100 \%$ bio-fertilizer. Values having the same alphabetical letter(s) in each column did not significantly different according to LSD at 5\% of probability.

that organic manures may be due to their high contents of $\mathrm{N}$ and their effects on soil properties, which maintaining soil $\mathrm{pH}$ near to the normal (El-Shafie and El-Shikha, 2003). Also the positive effect of organic fertilizers applied to soil may be due enriching the activity of bacteria which support the free availability of N, P as well as the other nutrients in the soil which improves the absorpting of nutrients by tomato roots (Bertand and Cleyetmarel, 2008). In addition, this increasing might be attributed to that organic fertilizer improve physical, chemical and biological soil components, as well as increasing soil organic matter cation exchanging capacity, water holding capacity and available nutrients and this in turn increasing plant growth (Ramadan, 2010). Ibrahim and Fadni (2013) and Iwuagwu et al. (2013) reported that organic fertilizer significantly increased dry weight of tomato parts. Also such increment might be attributed to bacteria of the genus Azotobacter produce auxins, cytokinins, and GA-like substances and these growth supplies are the main material controlling the higher growth of tomato (Azcón and Barea, 1975). Also phytohormones (auxin, cytokinin, gibberellin) can stimulate root development (Wani et al., 2013). Moreover it has been reported that Bacillus create compunds which help plant growth directly or indirectly like., hydrogen cyanide $(\mathrm{HCN})$, siderophores, indole acetic acid (IAA), dissolving phosphorous and antifungal activity (Shobha and Kumudini, 2012). These bacterial phytohormones might play a vital role in increasing dry weight of tomato. Lira-Saldivar et al. (2014), Mehta et al. (2015) and Mahesha et al. (2018) indicated that biofertlizer enhanced dry weight of tomato parts. All the previous findings might helped tomato plants to withstand the high temperature 


\section{Moustafa, et al.}

by supported them with nutrients that lead to produce a strong vegetative growth and increased dry weight of plant parts. The results are in the line with Mesallam et al. (2017) and Dawa et al. (2013) who found that the interaction of biofertlizer with mineral and organic significantly increased dry weight of plant parts.

Effect of the interaction between hybrids and different fertilization sources on the dry weight of tomato plant parts under high temperature conditions

Using Alia123 $\left(\mathrm{V}_{1}\right)$ hybrid with mixture of $\left(\mathrm{T}_{4}\right)$ were the superior interaction treatments which enhanced dry weight of shoots and total dry weight/ plant in the both seasons. Moreover, leaves dry weight came in the first rank in Rama 888 hybrid $\left(\mathrm{V}_{1}\right)$ with a mixture of $100 \%$ minerals $+100 \%$ bio-fertilizer $+100 \%$ organic in the first season and Alia123 hybrid $\left(\mathrm{V}_{1}\right)$ with a mixture of $100 \%$ mineral $+100 \%$ bio-fertilizer+ $100 \%$ organic fertilizer in the second season. In addition, as compared with the other interaction treatments Alia123 hybrid $\left(\mathrm{V}_{2}\right)$ fertilized with $100 \%$ mineral + bio-fertilizer + organic fertilizer increased roots dry weight per plant in the first season and Rama888 hybrid $\left(\mathrm{V}_{2}\right)$ fertilized with $100 \%$ minerals + bio-fertilizer + organic fertilizer in the second season (Table 3).

\section{Flowering and Fruit Setting}

\section{Effect of tomato hybrids on flowering and fruit setting under high temperature conditions}

As shown in Table 4, the number of flowers per plant, number of clusters per plant, as well as number of fruits setting (from 20 flowers) and its percentage were significantly increased in Rama888 hybrid $\left(\mathrm{V}_{2}\right)$ than Alia123 $\left(\mathrm{V}_{1}\right)$ under the average air temperature of 20 days (40.1/ $26.9^{\circ} \mathrm{C}$ day/night), Except for the number of fruits per cluster which didn't reflect any significant effect between both hybrids. This difference might be due the genetic variation between both tomato hybrids in heat stress tolerance. Furthermore, it may be attributed to the impact of high temperature on pollen viability, flowering and fruit setting processes are better in $V_{2}$ due to its resistance to heat stress. The results are in harmony with Rahaman et al. (2011) and Abdul Rasool and Abeedhabeeb (2014) on flowering stage and fruit set of tomato varieties, they showed that tomato hybrids differed in fruit setting and flowering characters.

Effect of different fertilization sources on the flowering and fruit setting of tomato plants grown under high temperature conditions

It was interesting to note that $\left(\mathrm{T}_{4}\right.$ significantly enhanced the number of flowers per plant and number of clusters per plant. Furthermore, $\left(\mathrm{T}_{4}\right)$ and $\left(T_{5}\right)$ increased number of fruits per cluster and number of fruits setting and its percentage (known 20 flowers) without any significant effect between them under the average air temperature of 20 days $\left(40.1 / 26.9^{\circ} \mathrm{C}\right.$ day/night). This increment may be because of available nitrogen and phosphorus available have a positive influence on flower initiation (Table 4). Nitrogen and phosphorus caused better performance in flower initiation and fruit setting in tomato (Balemi, 2008). Another possible cause is the additional supply of vital nutrients to tomato plants, enhanced their availability, acquisition, mobilization and influx into the plant tissues which increased both numbers of flower and fruits cluster/plant (Shukla et al., 2009). Alawathugoda and Dahanayake (2013) and Mishra et al. (2016) reported that mineral fertilizer, improved flowering and fruit set of tomato plants. Another reason is may poultry manure application released nutrients especially NPK which in role increased flowering and fruit setting under high temperature conditions, (Ilodibia and Chukwuma, 2015). Islam et al. (2017) demonstrated that organic manure increases flowering characters and fruits setting of tomato. Moreover, this increase might be related with the effective fixation of nitrogen, as well as metabolic products of Azotobacter as gibberellins, indole acetic acid and cytokinin might have helped in inducing early flowering, fruit setting, fruit picking and also improved number of flowers and fruits per cluster this lead to increase of the yield (Bhadoria et al., 2007). According to the biofertlizer effect on characters and fruits setting of tomato plants, Meena $e t a l$. (2014) reported that bio-fertilizer significantly improved flowering characters and fruits setting 
Zagazig J. Agric. Res., Vol. 46 No. (6A) 2019

Table 3. Effect of the interaction between tomato hybrids and different fertilization sources on the dry weight of tomato plant parts grown under high temperature conditions during the 2016 and 2017 seasons.

\begin{tabular}{|c|c|c|c|c|c|c|c|c|c|}
\hline \multirow[b]{3}{*}{$\begin{array}{l}\text { Tomato } \\
\text { hybrids }\end{array}$} & \multirow[b]{3}{*}{$\begin{array}{c}\text { Fertilization } \\
\text { treatments }\end{array}$} & \multicolumn{8}{|c|}{ Dry weight/ plant (g) } \\
\hline & & \multicolumn{4}{|c|}{2016 season } & \multicolumn{4}{|c|}{2017 season } \\
\hline & & Leaves & Roots & Shoots & Total & Leaves & Roots & Shoots & Total \\
\hline \multirow{7}{*}{$\mathbf{V}_{1} \times$} & $\mathbf{T}_{1}$ & $55.740 \mathrm{c}$ & $12.103 \mathrm{bc}$ & $66.112 \mathrm{ab}$ & $133.96 \mathrm{c}$ & $59.245 \mathrm{~b}$ & $11.527 \mathrm{c}$ & $66.698 \mathrm{~b}$ & $137.47 \mathrm{~b}$ \\
\hline & $\mathbf{T}_{2}$ & $39.967 \mathrm{f}$ & $9.725 \mathrm{de}$ & $43.652 \mathrm{e}$ & $93.34 \mathrm{~g}$ & $42.535 \mathrm{hi}$ & $8.715 \mathrm{~d} \mathrm{e}$ & $45.650 \mathrm{efg}$ & $96.90 \mathrm{gh}$ \\
\hline & $\mathbf{T}_{3}$ & $43.075 \mathrm{ef}$ & $11.683 \mathrm{bc}$ & $50.600 \mathrm{~d}$ & $105.36 \mathrm{f}$ & $52.705 \mathrm{de}$ & $12.933 \mathrm{abc}$ & $57.810 \mathrm{~d}$ & $123.45 \mathrm{c}$ \\
\hline & $\mathbf{T}_{4}$ & $66.125 \mathrm{a}$ & $13.775 \mathrm{a}$ & $70.092 \mathrm{a}$ & $149.99 \mathrm{a}$ & $67.000 \mathrm{a}$ & $13.943 \mathrm{ab}$ & $72.400 \mathrm{a}$ & $153.34 \mathrm{a}$ \\
\hline & $\mathbf{T}_{5}$ & $57.967 \mathrm{bc}$ & $13.850 \mathrm{a}$ & $64.325 \mathrm{bc}$ & $135.14 \mathrm{bc}$ & $58.777 \mathrm{~b}$ & $14.277 \mathrm{ab}$ & $64.397 \mathrm{bc}$ & $137.45 \mathrm{~b}$ \\
\hline & $\mathbf{T}_{6}$ & $51.425 \mathrm{~d}$ & $13.075 \mathrm{ab}$ & $61.058 \mathrm{c}$ & $125.56 \mathrm{~d}$ & $49.100 \mathrm{fg}$ & $12.807 \mathrm{abc}$ & $58.360 \mathrm{~d}$ & $120.27 \mathrm{c}$ \\
\hline & $\mathbf{T}_{7}$ & $44.200 \mathrm{e}$ & $10.950 \mathrm{~cd}$ & $53.175 \mathrm{~d}$ & $108.33 \mathrm{f}$ & $44.090 \mathrm{hi}$ & $12.840 \mathrm{abc}$ & 47.417 ef & 104.35 ef \\
\hline \multirow[t]{7}{*}{$\mathbf{V}_{2} \times$} & $\mathbf{T}_{1}$ & $56.100 \mathrm{bc}$ & $12.673 \mathrm{ab}$ & $52.550 \mathrm{~d}$ & $121.32 \mathrm{de}$ & $57.265 \mathrm{bc}$ & $10.895 \mathrm{~cd}$ & $55.690 \mathrm{~d}$ & $123.85 \mathrm{c}$ \\
\hline & $\mathbf{T}_{2}$ & $33.425 \mathrm{~g}$ & $9.000 \mathrm{e}$ & $34.625 \mathrm{~g}$ & $77.05 \mathrm{~h}$ & $41.540 \mathrm{i}$ & $8.605 \mathrm{e}$ & $42.170 \mathrm{~g}$ & $92.31 \mathrm{~h}$ \\
\hline & $\mathbf{T}_{3}$ & $45.800 \mathrm{e}$ & $11.900 \mathrm{bc}$ & $39.200 \mathrm{f}$ & $96.02 \mathrm{~g}$ & 50.257 ef & $10.773 \mathrm{~cd}$ & $45.705 \mathrm{fg}$ & $106.73 \mathrm{e}$ \\
\hline & $\mathbf{T}_{4}$ & $66.225 \mathrm{a}$ & $13.025 \mathrm{ab}$ & $61.900 \mathrm{bc}$ & $141.15 \mathrm{~b}$ & $65.467 \mathrm{a}$ & $14.350 \mathrm{a}$ & $62.473 \mathrm{c}$ & $142.29 \mathrm{~b}$ \\
\hline & $\mathbf{T}_{5}$ & $59.585 \mathrm{~b}$ & $12.667 \mathrm{ab}$ & $53.750 \mathrm{~d}$ & $126.00 \mathrm{~d}$ & $57.240 \mathrm{bc}$ & $12.227 \mathrm{bc}$ & $54.940 \mathrm{~d}$ & $124.41 \mathrm{c}$ \\
\hline & $\mathbf{T}_{6}$ & $55.600 \mathrm{c}$ & $12.090 \mathrm{bc}$ & $50.892 \mathrm{~d}$ & $118.58 \mathrm{e}$ & $54.767 \mathrm{~cd}$ & $11.287 \mathrm{c}$ & $48.290 \mathrm{e}$ & $114.34 \mathrm{~d}$ \\
\hline & $\mathbf{T}_{7}$ & $44.950 \mathrm{e}$ & $11.033 \mathrm{~cd}$ & 41.717 ef & $97.70 \mathrm{~g}$ & $45.800 \mathrm{gh}$ & $10.623 \mathrm{~cd}$ & $43.993 \mathrm{fg}$ & $100.42 \mathrm{fg}$ \\
\hline
\end{tabular}

$\mathrm{V}_{1}$ : Alia123 hybrid, $\mathrm{V}_{2}:$ Rama888 hybrid, $\mathrm{T}_{1}: 100 \%$ mineral fertilizers, $\mathrm{T}_{2}: 100 \%$ bio-fertilizers, $\mathrm{T}_{3}: 100 \%$ organic manure, $\mathrm{T}_{4}$ : $100 \%$ mineral $+100 \%$ organic manure $+100 \%$ bio-fertilizer, $\mathrm{T}_{5}: 75 \%$ mineral $+100 \%$ organic manure $+100 \%$ bio-fertilizer, $\mathrm{T}_{6}$ : $50 \%$ mineral $+100 \%$ organic manure $+100 \%$ bio-fertilizer, $\mathrm{T}_{7}: 25 \%$ mineral $+100 \%$ organic manure $+100 \%$ bio-fertilizer. Values having the same alphabetical letter(s) in each column did not significantly different according to LSD at 5\% of probability.

Table 4. Effect of tomato hybrids and different fertilization sources on the fowering and fruit set of tomato plants grown under high temperature conditions during 2017 season

\begin{tabular}{|c|c|c|c|c|c|}
\hline \multicolumn{6}{|c|}{ Flowering and fruit setting (2017 season) } \\
\hline $\begin{array}{l}\text { Tomato } \\
\text { hybrids }\end{array}$ & $\begin{array}{c}\text { No. flowers/ } \\
\text { plant }\end{array}$ & $\begin{array}{l}\text { No. fruits/ } \\
\text { cluster }\end{array}$ & $\begin{array}{c}\text { No. clusters/ } \\
\text { plant }\end{array}$ & $\begin{array}{l}\text { No. fruits } \\
\text { setting }\end{array}$ & $\begin{array}{c}\text { Fruits setting } \\
(\%)^{*}\end{array}$ \\
\hline & \multicolumn{5}{|c|}{ Effect of tomato hybrids } \\
\hline $\mathbf{V}_{1}$ & $80.443 \mathrm{~b}$ & $4.1905 \mathrm{a}$ & $6.9865 \mathrm{~b}$ & $12.850 \mathrm{~b}$ & $64.250 \mathrm{~b}$ \\
\hline $\mathbf{V}_{2}$ & $82.300 \mathrm{a}$ & $4.4048 \mathrm{a}$ & $8.2190 \mathrm{a}$ & $15.162 \mathrm{a}$ & $75.810 \mathrm{a}$ \\
\hline & \multicolumn{5}{|c|}{ Effect of different fertilization sources } \\
\hline $\begin{array}{r}\text { Fertilizatio } \\
\text { treatments }\end{array}$ & & & & & \\
\hline $\mathbf{T}_{1}$ & $81.000 \mathrm{e}$ & $4.1667 \mathrm{~b}$ & $7.4091 \mathrm{~b}$ & $13.483 \mathrm{~d}$ & $67.417 \mathrm{~d}$ \\
\hline $\mathbf{T}_{2}$ & $52.325 \mathrm{f}$ & $3.5000 \mathrm{c}$ & $4.1855 \mathrm{c}$ & $9.333 \mathrm{e}$ & $46.667 \mathrm{e}$ \\
\hline $\mathbf{T}_{\mathbf{3}}$ & $80.075 \mathrm{e}$ & $4.2500 \mathrm{~b}$ & $7.7465 \mathrm{~b}$ & $13.833 \mathrm{~cd}$ & $69.167 \mathrm{~cd}$ \\
\hline $\mathbf{T}_{4}$ & $96.500 \mathrm{a}$ & $5.0833 \mathrm{a}$ & $9.6319 \mathrm{a}$ & $16.408 \mathrm{a}$ & $82.042 \mathrm{a}$ \\
\hline $\mathbf{T}_{5}$ & $89.550 \mathrm{~b}$ & $4.7500 \mathrm{ab}$ & $8.1611 \mathrm{~b}$ & $15.533 \mathrm{ab}$ & $77.667 \mathrm{ab}$ \\
\hline $\mathbf{T}_{6}$ & $86.325 \mathrm{c}$ & $4.1667 \mathrm{~b}$ & $8.0736 \mathrm{~b}$ & $14.983 \mathrm{bc}$ & $74.917 \mathrm{bc}$ \\
\hline $\mathbf{T}_{7}$ & $83.825 \mathrm{~d}$ & $4.1667 \mathrm{~b}$ & $8.0114 \mathrm{~b}$ & $14.467 \mathrm{bcd}$ & $72.333 \mathrm{bcd}$ \\
\hline
\end{tabular}

$\mathrm{V}_{1}:$ Alia123 hybrid, $\mathrm{V}_{2}:$ Rama888 hybrid, $\mathrm{T}_{1}: 100 \%$ mineral fertilizers, $\mathrm{T}_{2}: 100 \%$ bio-fertilizers, $\mathrm{T}_{3}: 100 \%$ organic manure, $\mathrm{T}_{4}$ : $100 \%$ mineral $+100 \%$ organic manure $+100 \%$ bio-fertilizer, $\mathrm{T}_{5}: 75 \%$ mineral $+100 \%$ organic manure $+100 \%$ bio-fertilizer, $\mathrm{T}_{6}$ : $50 \%$ mineral $+100 \%$ organic manure $+100 \%$ bio-fertilizer, $\mathrm{T}_{7}: 25 \%$ mineral $+100 \%$ organic manure $+100 \%$ bio-fertilizer. Values having the same alphabetical letter(s) in each column did not significantly different according to LSD at 5\% of probability. * Fruits setting of known 20 flowers counted at $39.8 / 26.9^{\circ} \mathrm{c}$ day/night. 


\section{Moustafa, et al}

of tomato under high temperature. Similar results were compatible with the study of Rajeev and Sharma (2014), Meena et al. (2017) and Rajeev et al. (2017) on tomato reported that the interaction of mineral, organic and bio-fertilizer increased characters and fruits setting of tomato. On the other hand, Omar et al. (2018) on sweet pepper cv. Top Star showed that, the interaction of mineral, organic and biofertilizer increased characters and fruits setting.

Effect of the interaction between Hybrids and different fertilization sources under high temperature conditions

Results recorded in Table 5 show that using $\mathrm{T}_{4}$ mixture with Rama 888 hybrid was the superior interaction treatment which reflected a significant effect on the number of flowers per plant and number of clusters per plant. In addition $\mathrm{T}_{4}$ increased number of fruits per cluster, number and percentage of fruits setting (from 20 flowers) under the average air temperature of 20 days $\left(40.1 / 26.9^{\circ} \mathrm{C}\right.$ day/night) followed by $T_{5}$ and $T_{6}$ without any significant effect between them. On the other hand, using Alia123 tomato hybrid with $100 \%$ bio-fertilizer $\left(\mathrm{T}_{2}\right)$ has only been the lowest interaction treatment among the whole treatments on the above mentioned characters.

\section{Yield and its Components}

\section{Effect of tomato hybrids grown under} high temperature conditions

It is obvious from recorded results in Table 6 that, average fruit weight, number of fruits per plant, yield per plant early yield, as well as total yield in Rama888 hybrid $\left(\mathrm{V}_{2}\right)$ was significantly higher than Alia 123 hybrid $\left(\mathrm{V}_{1}\right)$ in the both studied seasons. The variances between the both hybrids might be due to their genetic variations for heat sensitivity. Therefore the high temperature caused a variation between them in yield and its components. Results are in the line with Ali et al. (2016), Bhati (2017) and Sivakumar and Srividhya (2016) on yield and its components of tomato genotypes.

Effect of different fertilization sources on tomato yield and its components under high temperature conditions

It is clear from Table 6 that, the application of a mixture $100 \%$ mineral $+100 \%$ bio-fertilizer $+100 \%$ organic fertilizer $\left(\mathrm{T}_{4}\right)$ to tomato plants significantly enhanced yield and its components, i.e., average fruit weight, number of fruits per plant, yield per plant, total yield in the both seasons as well as early yield in the first season compared to the other treatments. Moreover, $100 \%$ mineral $+100 \%$ bio-fertilizer $+100 \%$ organic fertilizer $\left(\mathrm{T}_{4}\right)$ came in the first rank which increased early yield followed by, $75 \%$ mineral $+100 \%$ bio-fertilizer $+100 \%$ organic fertilizer $\left(\mathrm{T}_{5}\right)$ in the second season. Increasing in the abovementioned characters might be attributed to increasing stimulating effect of nitrogen on the vegetative growth characters which in role improved flowering and fruiting. Furthermore vegetative activate more carbohydrates synthesis which later effect on yield quality and quantity (Bidari and Hebsur, 2011). In addition, potassium element absorbed by plants helped to increase photosynthesis, serving for more proteins and carbohydrates synthesis. Improved protein, fat and carbohydrate creation that is transferred to fruits which can lead to increase average fruit weight (Setyamidjaja, 1986). Earlier studies by scientists showed that potassium provides an vital role in fruit weight, fruit color, dry matter and the final yield of tomato (Anac et al., 1994). Iqbal et al. (2011) and Dhiman et al. (2018) found that mineral (NPK) fertilizer enhanced yield and its components of tomato plants. In addition, higher yield response of crops due to used organic manure could be enhanced the physical and biological properties of the soil which becam a better source of nutrients to the plants (Saidu $\boldsymbol{e t}$ al., 2011; Ekwu and Nwokwu, 2012; Tiamiyu et al., 2012). Abolusorob (2012), Geetharani and Parthiban (2014) and Mfombep et al. (2016) told that organic manure affected yield and its components. For bio-fertilizers containing treatments increases yield might be due to increased nitrogen supply by Azotobacter application which might be responsible for healthy growth and improved chlorophyll content, which in turn accelerated photosynthetic rate and thereby increased the supply of carbohydrate to plant (Shafi et al., 2019). Moreover the increase in fruit yield of tomato with inoculation of $\mathrm{P}$ solubilizing bacteria might be back to increasing in $\mathrm{P}$ availability through dissolving inorganic phosphate by organic acid, breakdown of phosphate-rich organic compounds and production of plant growth supporting substances (Gaur and Sunita, 1999). Abdel-Monaim et al. (2012), showed that bio-fertilizer increased yield and its's components. Ho (1996) and Adams et al. (2001) told that high tomato under high temperature 
Zagazig J. Agric. Res., Vol. 46 No. (6A) 2019

Table 5. Effect of the interaction between tomato hybrids and different fertilization sources on the flowering and fruit set of tomato plants grown under high temperature conditions during the 2017 season.

\begin{tabular}{ccccccc}
\hline $\begin{array}{c}\text { Tomato } \\
\text { hybrid }\end{array}$ & $\begin{array}{c}\text { Fertilization } \\
\text { treatment }\end{array}$ & \multicolumn{5}{c}{ Flowering and fruit settings (2017 season) } \\
\cline { 3 - 7 } & $\begin{array}{c}\text { No. flowers/ } \\
\text { plant }\end{array}$ & $\begin{array}{c}\text { No. fruits/ } \\
\text { cluster }\end{array}$ & $\begin{array}{c}\text { No. clusters/ } \\
\text { plant }\end{array}$ & No. setting fruits & $\begin{array}{c}\text { Setting fruits } \\
(\%)\end{array}$ \\
\hline & $\mathbf{T}_{\mathbf{1}}$ & $80.5 \mathrm{gh}$ & $4.16 \mathrm{bcd}$ & $6.977 \mathrm{~d}$ & $12.5 \mathrm{ef}$ & $62.5 \mathrm{ef}$ \\
& $\mathbf{T}_{\mathbf{2}}$ & $51.7 \mathrm{i}$ & $3.16 \mathrm{e}$ & $3.877 \mathrm{e}$ & $7.5 \mathrm{~g}$ & $37.5 \mathrm{~g}$ \\
$\mathbf{V}_{\mathbf{1}} \times$ & $\mathbf{T}_{\mathbf{3}}$ & $79.15 \mathrm{~h}$ & $4.33 \mathrm{abcd}$ & $6.825 \mathrm{~d}$ & $12.6 \mathrm{ef}$ & $63 \mathrm{ef}$ \\
& $\mathbf{T}_{\mathbf{4}}$ & $94 \mathrm{~b}$ & $5 \mathrm{ab}$ & $8.261 \mathrm{bcd}$ & $15.75 \mathrm{abc}$ & $78.75 \mathrm{abc}$ \\
& $\mathbf{T}_{\mathbf{5}}$ & $87.2 \mathrm{c}$ & $4.66 \mathrm{abcd}$ & $7.270 \mathrm{~cd}$ & $14.7 \mathrm{bcd}$ & $73.5 \mathrm{bcd}$ \\
& $\mathbf{T}_{\mathbf{6}}$ & $85.95 \mathrm{~cd}$ & $4 \mathrm{de}$ & $7.981 \mathrm{bcd}$ & $13.8 \mathrm{de}$ & $69 \mathrm{de}$ \\
& $\mathbf{T}_{\mathbf{7}}$ & $84.6 \mathrm{de}$ & $4 \mathrm{cde}$ & $7.714 \mathrm{bcd}$ & $13.1 \mathrm{de}$ & $65.5 \mathrm{de}$ \\
& $\mathbf{T}_{\mathbf{1}}$ & $81.5 \mathrm{fg}$ & $4.16 \mathrm{bcd}$ & $7.841 \mathrm{bcd}$ & $14.46 \mathrm{~cd}$ & $72.33 \mathrm{~cd}$ \\
& $\mathbf{T}_{\mathbf{2}}$ & $52.95 \mathrm{i}$ & $3.83 \mathrm{de}$ & $4.494 \mathrm{e}$ & $11.16 \mathrm{f}$ & $55.83 \mathrm{f}$ \\
$\mathbf{V}_{\mathbf{2}} \times$ & $\mathbf{T}_{\mathbf{3}}$ & $81 \mathrm{f} \mathrm{gh}$ & $4.16 \mathrm{bcd}$ & $8.668 \mathrm{bc}$ & $14.56 \mathrm{bcd}$ & $72.83 \mathrm{bcd}$ \\
& $\mathbf{T}_{\mathbf{4}}$ & $99 \mathrm{a}$ & $5.16 \mathrm{a}$ & $11.003 \mathrm{a}$ & $17.06 \mathrm{a}$ & $85.33 \mathrm{a}$ \\
& $\mathbf{T}_{\mathbf{5}}$ & $91.9 \mathrm{~b}$ & $4.83 \mathrm{abc}$ & $9.052 \mathrm{~b}$ & $16.36 \mathrm{a}$ & $81.83 \mathrm{a}$ \\
& $\mathbf{T}_{\mathbf{6}}$ & $86.7 \mathrm{~cd}$ & $4.33 \mathrm{abcd}$ & $8.167 \mathrm{bcd}$ & $16.33 \mathrm{a}$ & $81.67 \mathrm{a}$ \\
& $\mathbf{T}_{\mathbf{7}}$ & $83.05 \mathrm{ef}$ & $4.33 \mathrm{abcd}$ & $8.308 \mathrm{bcd}$ & $16.16 \mathrm{ab}$ & $80.83 \mathrm{ab}$ \\
\hline
\end{tabular}

$\mathrm{V}_{1}:$ Alia123 hybrid, $\mathrm{V}_{2}:$ Rama888 hybrid, $\mathrm{T}_{1}: 100 \%$ mineral fertilizers, $\mathrm{T}_{2}: 100 \%$ bio-fertilizers, $\mathrm{T}_{3}: 100 \%$ organic manure, $\mathrm{T}_{4}$ : $100 \%$ mineral $+100 \%$ organic manure $+100 \%$ bio-fertilizer, $\mathrm{T}_{5}: 75 \%$ mineral $+100 \%$ organic manure $+100 \%$ bio-fertilizer, $\mathrm{T}_{6}$ : $50 \%$ mineral $+100 \%$ organic manure $+100 \%$ bio-fertilizer, $\mathrm{T}_{7}: 25 \%$ mineral $+100 \%$ organic manure $+100 \%$ bio-fertilizer. Values having the same alphabetical letter(s) in each column did not significantly different according to LSD at 5\% of probability.

Table 6. Effect of tomato hybrids and different fertilization sources with its rates on the yield and its components of tomato plants grown under high temperature conditions during 2016 and 2017 seasons

\begin{tabular}{|c|c|c|c|c|c|c|c|c|c|c|}
\hline \multirow{3}{*}{$\begin{array}{l}\text { Tomato } \\
\text { hybrid }\end{array}$} & \multicolumn{10}{|c|}{ Yield and its components } \\
\hline & \multicolumn{5}{|c|}{2016 season } & \multicolumn{5}{|c|}{2017 season } \\
\hline & $\begin{array}{l}\text { No. fruits/ } \\
\text { plant }\end{array}$ & $\begin{array}{c}\text { Yield/ } \\
\text { Plant } \\
\text { (kg) }\end{array}$ & $\begin{array}{c}\text { Early } \\
\text { yield } \\
\text { (ton/fad.) }\end{array}$ & $\begin{array}{c}\text { Total } \\
\text { yield } \\
\text { (ton/fad.) }\end{array}$ & $\begin{array}{l}\text { Ava. fruit } \\
\text { weigh } \\
\text { (g) }\end{array}$ & $\begin{array}{l}\text { No. } \\
\text { fruits } \\
\text { /plant }\end{array}$ & $\begin{array}{c}\text { Yield/ } \\
\text { Plant } \\
\text { (kg) }\end{array}$ & $\begin{array}{c}\text { Early } \\
\text { yield } \\
\text { (ton/fad.) }\end{array}$ & $\begin{array}{c}\text { Total } \\
\text { yield } \\
\text { (ton/fad.) }\end{array}$ & $\begin{array}{l}\text { Ava. fruit } \\
\text { weigh } \\
\text { (g) }\end{array}$ \\
\hline & \multicolumn{10}{|c|}{ Effect of tomato hybrids } \\
\hline $\mathbf{V}_{1}$ & $28.762 \mathrm{~b}$ & $2.8858 \mathrm{~b}$ & $6.1855 b$ & $18.044 \mathrm{~b}$ & $97.97 \mathrm{~b}$ & $29.33 \mathrm{~b}$ & 2.975 & b $\quad 6.0212 b$ & $19.286 \mathrm{~b}$ & $99.26 \mathrm{~b}$ \\
\hline $\mathbf{V}_{2}$ & $33.655 \mathrm{a}$ & $3.4535 \mathrm{a}$ & $7.3238 \mathrm{a}$ & $20.547 \mathrm{a}$ & $00.08 \mathrm{a}$ & $35.27 \mathrm{a}$ & 3.509 & $7.4886 \mathrm{a}$ & $21.904 \mathrm{a}$ & $102.46 \mathrm{a}$ \\
\hline
\end{tabular}

Fertilization

Effect of different fertilization sources

\begin{tabular}{ccccccccccc}
$\begin{array}{c}\text { treatment } \\
\text { T }\end{array}$ & $28.667 \mathrm{~d}$ & $2.8465 \mathrm{~d}$ & $7.3167 \mathrm{bc}$ & $18.029 \mathrm{~d}$ & $99.28 \mathrm{~d}$ & $30.667 \mathrm{~d}$ & $2.9160 \mathrm{e}$ & $6.9567 \mathrm{bc}$ & $19.080 \mathrm{~d}$ & $101.12 \mathrm{~d}$ \\
$\mathbf{T}_{\mathbf{2}}$ & $15.208 \mathrm{e}$ & $1.1462 \mathrm{e}$ & $2.3776 \mathrm{e}$ & $7.322 \mathrm{e}$ & $75.32 \mathrm{e}$ & $14.708 \mathrm{e}$ & $1.1957 \mathrm{f}$ & $3.0990 \mathrm{~d}$ & $8.370 \mathrm{f}$ & $78.99 \mathrm{f}$ \\
$\mathbf{T}_{\mathbf{3}}$ & $28.875 \mathrm{~d}$ & $2.8509 \mathrm{~d}$ & $6.7894 \mathrm{c}$ & $17.126 \mathrm{~d}$ & $98.72 \mathrm{~d}$ & $31.375 \mathrm{~cd}$ & $2.7678 \mathrm{e}$ & $7.0716 \mathrm{bc}$ & $17.673 \mathrm{e}$ & $99.73 \mathrm{e}$ \\
$\mathbf{T}_{\mathbf{4}}$ & $43.333 \mathrm{a}$ & $4.6778 \mathrm{a}$ & $9.2649 \mathrm{a}$ & $26.395 \mathrm{a}$ & $107.84 \mathrm{a}$ & $45.500 \mathrm{a}$ & $4.8413 \mathrm{a}$ & $8.9517 \mathrm{a}$ & $28.250 \mathrm{a}$ & $109.84 \mathrm{a}$ \\
$\mathbf{T}_{\mathbf{5}}$ & $37.250 \mathrm{~b}$ & $3.9077 \mathrm{~b}$ & $8.0568 \mathrm{~b}$ & $23.708 \mathrm{~b}$ & $104.72 \mathrm{~b}$ & $38.750 \mathrm{~b}$ & $4.1756 \mathrm{~b}$ & $8.0742 \mathrm{ab}$ & $25.650 \mathrm{~b}$ & $107.05 \mathrm{~b}$ \\
$\mathbf{T}_{\mathbf{6}}$ & $32.917 \mathrm{c}$ & $3.4423 \mathrm{c}$ & $7.6167 \mathrm{~b}$ & $21.656 \mathrm{c}$ & $104.48 \mathrm{~b}$ & $32.750 \mathrm{c}$ & $3.5180 \mathrm{c}$ & $7.1126 \mathrm{bc}$ & $22.980 \mathrm{c}$ & $105.15 \mathrm{c}$ \\
$\mathbf{T}_{\mathbf{7}}$ & $32.208 \mathrm{c}$ & $3.3162 \mathrm{c}$ & $5.8603 \mathrm{~d}$ & $20.833 \mathrm{c}$ & $102.83 \mathrm{c}$ & $32.375 \mathrm{c}$ & $3.2806 \mathrm{~d}$ & $6.0183 \mathrm{c}$ & $22.159 \mathrm{c}$ & $104.16 \mathrm{c}$ \\
\hline
\end{tabular}

$\mathrm{V}_{1}$ : Alia123 hybrid, $\mathrm{V}_{2}$ : Rama888 hybrid, $\mathrm{T}_{1}: 100 \%$ mineral fertilizers, $\mathrm{T}_{2}: 100 \%$ bio-fertilizers, $\mathrm{T}_{3}: 100 \%$ organic manure, $\mathrm{T}_{4}$ : $100 \%$ mineral $+100 \%$ organic manure $+100 \%$ bio-fertilizer, $\mathrm{T}_{5}: 75 \%$ mineral $+100 \%$ organic manure $+100 \%$ bio-fertilizer, $\mathrm{T}_{6}$ : $50 \%$ mineral $+100 \%$ organic manure $+100 \%$ bio-fertilizer, $\mathrm{T}_{7}: 25 \%$ mineral $+100 \%$ organic manure $+100 \%$ bio-fertilizer. Values having the same alphabetical letter(s) in each column did not significantly different according to LSD at $5 \%$ of probability. 


\section{Moustafa, et al.}

produced poorer fruit yield of tomato. High temperature decreased carbohydrates and affect on plant biological processes that lead to lower fruit yield. The optimal temperature for fruiting development at night temperature is between 15 $-20^{\circ} \mathrm{C}$ and the day temperature at about $25^{\circ} \mathrm{C}$ (Kalloo, 1985). Increasing temperature above the optimum range especially at night increased respiratory rate and this lead to lose carbohydrates and give lower fruit yield. In the current study using different fertilization sources together including bio-fertilizers, organic and mineral fertilizers may be compensate the shortage of nutrients induced by high temperature. Furthermore, using bio-fertilizers as supportive for mineral fertilization helped the root to absorb more nutrients under high temperature. That's in role enriched the physiological process including photosynthesis which leads to increasing carbohydrates rate and this might enhanced fruit yield of tomato. The obtained results are in agreement with Ahmed $\boldsymbol{e t}$ al. (2013) Meena et al. (2017) and Le et al. (2018) they mentioned that combination of mineral, organic and bio-fertilizer increased yield and its components.

Effect of the interaction between hybrids and different fertilization sources under high temperature conditions

The results in Table 7 show that using Rama 888 hybrids $\left(\mathrm{V}_{2}\right)$ with a mixture of $100 \%$ mineral $+100 \%$ organic fertilizer $+100 \%$ biofertilizer fertilizer $\left(\mathrm{T}_{4}\right)$ were the best interaction treatment that significantly increased yield and its components, i.e. Average fruit weight, number of fruits per plant, yield per plant and total yield in both seasons as well as early yield in the first season which were listed in this table compared with other interaction treatments. In addition, the interaction between Rama888 hybrids $\left(\mathrm{V}_{2}\right)$ with a mixture of $100 \%$ mineral $+100 \%$ organic fertilizer $+100 \%$ bio-fertilizer $\left(\mathrm{T}_{4}\right)$ increased early yield followed by $75 \%$ mineral $+100 \%$ organic fertilizer $+100 \%$ biofertilizer $\left(\mathrm{T}_{5}\right)$ with the same hybrid without any significant effect between them in the second season.

Table 7. Effect of the interaction between tomato hybrids and different fertilization sources on the yield and its components of tomato plants grown under high temperature conditions during 2016 and 2017 seasons.

\begin{tabular}{|c|c|c|c|c|c|c|c|c|c|c|c|}
\hline \multirow[b]{3}{*}{$\begin{array}{l}\text { Tomato } \\
\text { hybrid }\end{array}$} & \multirow[b]{3}{*}{$\begin{array}{c}\text { Fertilization } \\
\text { treatment }\end{array}$} & \multicolumn{10}{|c|}{ Yield and its components } \\
\hline & & \multicolumn{5}{|c|}{2016 season } & \multicolumn{5}{|c|}{2017 season } \\
\hline & & $\begin{array}{c}\text { No. } \\
\text { fruits/ } \\
\text { plant }\end{array}$ & $\begin{array}{c}\text { Yield/ } \\
\text { plant } \\
\text { (kg) }\end{array}$ & $\begin{array}{c}\text { Early } \\
\text { yield } \\
\text { (ton/fad.) }\end{array}$ & $\begin{array}{c}\text { Total } \\
\text { yield } \\
\text { (ton/fad.) }\end{array}$ & $\begin{array}{l}\text { Ava. fruit } \\
\text { weigh } \\
\text { (g) }\end{array}$ & $\begin{array}{l}\text { No. } \\
\text { fruits/ } \\
\text { plant }\end{array}$ & $\begin{array}{l}\text { Yield/ } \\
\text { plant } \\
\text { (kg) }\end{array}$ & $\begin{array}{c}\text { Early } \\
\text { yield } \\
\text { (ton/fad.) }\end{array}$ & $\begin{array}{c}\text { Total } \\
\text { yield } \\
\text { (ton/fad.) }\end{array}$ & $\begin{array}{l}\text { Ava. fruit } \\
\text { weigh } \\
\text { (g) }\end{array}$ \\
\hline \multirow{7}{*}{$\mathbf{V}_{1} \times$} & $\overline{T_{1}}$ & $27.667 \mathrm{e}$ & 2.7243 f 7 & $7.024 \mathrm{~cd}$ & $17.465 \mathrm{gh}$ & $98.48 \mathrm{~g}$ & $29.00 \mathrm{~g}$ & $2.7646 \mathrm{hi}$ & $6.691 \mathrm{~cd}$ & $18.798 \mathrm{f}$ & $100.48 \mathrm{gh}$ \\
\hline & $\mathbf{T}_{2}$ & $13.583 \mathrm{~g}$ & $1.0190 \mathrm{~h} 1$ & $1.943 \mathrm{f}$ & $6.324 \mathrm{i}$ & $75.01 \mathrm{~h}$ & $12.25 \mathrm{i}$ & $0.9951 \mathrm{k}$ & $2.971 \mathrm{e}$ & $6.966 \mathrm{i}$ & $76.67 \mathrm{j}$ \\
\hline & $\mathbf{T}_{3}$ & $27.250 \mathrm{e}$ & $2.6778 \mathrm{f} 5$ & $5.957 \mathrm{de}$ & $16.828 \mathrm{~h}$ & $98.32 \mathrm{~g}$ & $29.25 \mathrm{~g}$ & $2.6039 \mathrm{i}$ & $6.386 \mathrm{~cd}$ & $17.127 \mathrm{~g}$ & $98.98 \mathrm{~h}$ \\
\hline & $\mathbf{T}_{4}$ & $39.167 \mathrm{~b}$ & 4.1797 & $8.212 \mathrm{~b}$ & $24.974 \mathrm{BC}$ & $106.72 \mathrm{~b}$ & $40.5 \mathrm{c}$ & $4.3758 \mathrm{c}$ & $7.839 \mathrm{c}$ & $25.809 \mathrm{c}$ & $108.05 \mathrm{bc}$ \\
\hline & $\mathbf{T}_{5}$ & $33.167 \mathrm{c}$ & $3.4212 \mathrm{~d} 7$ & $7.440 \mathrm{bc}$ & $21.685 \mathrm{de}$ & $103.10 \mathrm{de}$ & $33.83 \mathrm{de}$ & $3.5913 \mathrm{de}$ & $6.615 \mathrm{~cd}$ & $24.045 \mathrm{~d}$ & $105.10 \mathrm{de}$ \\
\hline & $\mathbf{T}_{6}$ & $30.833 \mathrm{~d}$ & $3.1740 \mathrm{e} 7$ & $7.607 \mathrm{bc}$ & $20.070 \mathrm{ef}$ & $102.93 \mathrm{de}$ & $30.5 \mathrm{fg}$ & $3.2899 \mathrm{fg}$ & $6.365 \mathrm{~cd}$ & $21.471 \mathrm{e}$ & $103.27 \mathrm{ef}$ \\
\hline & $\mathbf{T}_{7}$ & $29.667 \mathrm{~d}$ & 3.0046 e 5 & $5.115 \mathrm{e}$ & $18.963 \mathrm{fg}$ & 101.25 ef & $30.00 \mathrm{~g}$ & $3.2050 \mathrm{fg}$ & $5.281 \mathrm{~d}$ & $20.783 \mathrm{e}$ & $102.25 \mathrm{fg}$ \\
\hline \multirow[t]{7}{*}{$V_{2} \times$} & $T_{1}$ & $29.667 \mathrm{de}$ & $2.9688 \mathrm{e}$ & $7.610 \mathrm{bc}$ & $18.594 \mathrm{fgh}$ & $100.08 \mathrm{fg}$ & $32.33 \mathrm{ef}$ & $3.0673 \mathrm{gh}$ & $7.222 \mathrm{c}$ & $19.363 \mathrm{f}$ & $101.75 \mathrm{fg}$ \\
\hline & $\mathbf{T}_{2}$ & $16.833 \mathrm{f}$ & $1.2734 \mathrm{~g}$ & $2.812 \mathrm{f}$ & $8.319 \mathrm{i}$ & $75.63 \mathrm{~h}$ & $17.167 \mathrm{~h}$ & $1.3963 \mathrm{j}$ & $3.227 \mathrm{e}$ & $9.774 \mathrm{~h}$ & $81.30 \mathrm{i}$ \\
\hline & $\mathbf{T}_{3}$ & $30.500 \mathrm{~d}$ & $3.0239 \mathrm{e}$ & $7.622 b c$ & $17.423 \mathrm{gh}$ & $99.13 \mathrm{~g}$ & $33.50 \mathrm{de}$ & 2.9317ghi & $7.757 \mathrm{c}$ & $18.219 \mathrm{fg}$ & $100.47 \mathrm{gh}$ \\
\hline & $\mathbf{T}_{4}$ & $47.500 \mathrm{a}$ & $5.1759 \mathrm{a}$ & $10.317 \mathrm{a}$ & $27.816 \mathrm{a}$ & $108.97 \mathrm{a}$ & $50.50 \mathrm{a}$ & $5.3068 \mathrm{a}$ & $10.065 \mathrm{a}$ & $30.690 \mathrm{a}$ & $111.63 \mathrm{a}$ \\
\hline & $\mathbf{T}_{5}$ & $41.333 b$ & $4.3943 \mathrm{~b}$ & $8.674 \mathrm{~b}$ & $25.731 \mathrm{~b}$ & $106.33 b c$ & $43.667 \mathrm{~b}$ & $4.7599 \mathrm{~b}$ & $9.534 a b$ & $27.254 \mathrm{~b}$ & $109.00 \mathrm{~b}$ \\
\hline & $T_{6}$ & $35.000 \mathrm{c}$ & $3.7107 \mathrm{c}$ & $7.626 b c$ & $23.243 \mathrm{~cd}$ & $106.03 \mathrm{bc}$ & $35.00 \mathrm{~d}$ & $3.7460 \mathrm{~d}$ & $7.860 \mathrm{bc}$ & $24.489 \mathrm{~cd}$ & $107.02 \mathrm{~cd}$ \\
\hline & $\mathbf{T}_{7}$ & $34.750 \mathrm{c}$ & $3.6279 \mathrm{~cd}$ & $6.606 \mathrm{~cd}$ & $22.702 \mathrm{~d}$ & $104.40 \mathrm{~cd}$ & $34.75 \mathrm{~d}$ & $3.3561 \mathrm{ef}$ & $6.756 \mathrm{~cd}$ & $23.535 \mathrm{~d}$ & $106.07 \mathrm{~cd}$ \\
\hline
\end{tabular}

$\mathrm{V}_{1}$ : Alia123 hybrid, $\mathrm{V}_{2}:$ Rama888 hybrid, $\mathrm{T}_{1}: 100 \%$ mineral fertilizers, $\mathrm{T}_{2}: 100 \%$ bio-fertilizers, $\mathrm{T}_{3}: 100 \%$ organic manure, $\mathrm{T}_{4}$ : $100 \%$ mineral $+100 \%$ organic manure $+100 \%$ bio-fertilizer, $\mathrm{T}_{5}: 75 \%$ mineral $+100 \%$ organic manure $+100 \%$ bio-fertilizer, $\mathrm{T}_{6}$ : $50 \%$ mineral $+100 \%$ organic manure $+100 \%$ bio-fertilizer, $\mathrm{T}_{7}: 25 \%$ mineral $+100 \%$ organic manure $+100 \%$ bio-fertilizer. Values having the same alphabetical letter(s) in each column did not significantly different according to LSD at $5 \%$ of probability. 


\section{Conclusion}

The previous study indicated that Alia123 $\left(\mathrm{V}_{1}\right)$ tomato hybrid significantly increased dry weight of shoots per plant and total dry weight, while Rama888 $\left(\mathrm{V}_{2}\right)$ tomato hybrid significantly enhanced number of flowers per plant, number of fruits per cluster, number of clusters per plant as well as number of fruits setting and its percentage (from 20 flowers) as well as yield and its compontes. $100 \%$ mineral+ $100 \%$ organic manure $+100 \%$ bio-fertilizer $\left(\mathrm{T}_{4}\right)$ improved all dry weight parameters, flowering and fruits setting characters as well as yield and its components. Alia123 $\left(\mathrm{V}_{1}\right)$ hybrid with a mixture of $100 \%$ minerals $+100 \%$ organic fertilizer + $100 \%$ bio-fertilizer $\left(\mathrm{T}_{4}\right)$ significantly enhanced all dry weight parameters, while Rama 888 hybrid $\left(\mathrm{V}_{2}\right)$ with the same mixture enhanced all flowering and fruit set characters, as well as yield and its component, in most cases.

\section{REFERENCES}

Abdelhady, S.A., N.A.A. El-Azm and E.S.H. ElKafafi (2017). Effect of deficit irrigation levels and NPK fertilization rates on tomato growth, yield and fruits quality. Middle East J., 6 (3): 587-604.

Abdellatif, I.M.Y., Y.Y. Abdel-Ati, Y.T. Abdel-Mageed and M.A.M.M. Hassan (2017). Effect of humic acid on growth and productivity of tomato plants under heat stress. J. Hort. Res., 25 (2): 59-66.

Abdel-Monaim, M.F., M.A. Abdel-Gaid and M.E.M.A. El-Morsy (2012). Efficacy of rhizobacteria and humic acid for controlling Fusarium wilt disease and improvement of plant growth, quantitative and qualitative parameters in tomato. Int. J. Phytopathol., 1 (1): 39-48.

Abdul Rasool, I.J. and S.T. Abeedhabeeb (2014). Response of different tomato genotypes to nitrogen foliar application and its effect on growth and production. J. Int. Acad. Res. Multidisciplinary, 2(8): 294-304.

Abolusorob, P. (2012). Effects of organic manure types on the growth, yield as well as root and soil populations of root-knot nematodes (Meloidogyne incognita) of tomato. Sci. J. Agric., 1(5): 138-144.
Adams, S.R., K.E. Cockshull and C.R.J. Cave (2001). Effect of temperature on the growth and development of tomato fruits. Ann. Bot., 88: 869-877.

Ahmed, A.M., R.H.M. Gheeth and R.M. Galal (2013). Integration between bio, organic and mineral nitrogen fertilization and its effect on growth, fruit yield and quality of tomato (Solanum lycopersicon L.) Assiut J. Agric. Sci., 44 (2): 55-70.

Alawathugoda, C. and N. Dahanayake (2013). Effects of mycorrhizae as a substitute for inorganic fertilizer on growth and yield of tomato (Lycopersicon esculentum L.) and soybean (Glycine $\max$ L.) and soil microbial activity. Tropical Agric. Res. and Ex., 16 (4): 108-112.

Alexander, M. (1985). Introduction to Soil Microbiology. John Wiley and Sons Inc., New Yourk, USA: 382-385.

Ali, A., I. Hussain, A. Khan, J. Khan, M.U. Rehman and A. Riaz (2016). Evaluation of various tomato (lycopersicon esculentum mill.) cultivars for quality, yield and yield components under agro climatic condition of Peshawar. ARPN J. Agric. and Biol. Sci., 11 (2): 59-62.

Alofe, C.O. and O. Somade (1982). Influence of spacing on the performance of three cultivars of tomato Nigeria. J. Sci., 16 (1 and 2): 119127.

Anac, D., N. Eryuce and R. Kilinc (1994). Effect of N, P, K fertilizer levels on yield and quality properties of processing tomatoes in Turkey. Acta. Hort., 376: 243-250.

Azcón, R. and J.M. Barea (1975). Synthesis of auxins, gibberellins and cytokinins by Azotobacter vinelandii and Azotobacter beijerinckii related to effects produced on tomato plants. Plant and Soil, 43 (1-3): 609619.

Balemi, T. (2008). Response of tomato cultivars differing in growth habit to nitrogen and phosphorus fertilizers and spacing on vertisol in Ethiopia. Acta Agric. Slovenica, 91 (1): 103-119.

Bertand, H.C. and J.C. Cleyetmarel (2008). Stimulation on the ionic transport system in tomato plants. Can. J. Microbial., 66: 922930. 


\section{Moustafa, et al.}

Bhadoria, S.K.S., Y.C. Dwivedia and S.S. Kushwah (2007). Flowering and fruiting behaviour of tomato as affected by Azotobacter and nitrogen. Indian J. Hort., 64 (3): 366-368.

Bhati, V. (2017). Evaluation of tomato genotypes for growth, yield and quality traits under foothills condition of Nagaland, India. Int. J. Curr. Microbiol. Appl. Sci, 6 (3): 1645 $-1649$.

Bidari, B.I. and N.S. Hebsur (2011). Potassium in relation to yield and quality of selected vegetable crops. Karnataka J. Agric. Sci., 24 $: 1$.

Blay, E.T., E.Y. Danquah, J. Ofosu-Anim and J.K. Ntumy (2002). Effect of poultry manure on the yield of shallot. Adv. Hort. Sci., 16 : 13-16.

Dawa, K.K.A., T.M. Al-Gazar and A.M. AbdelFatah (2013). Effect of chicken manure combined with bio-fertilizers, mineral fertilizer and some foliar applications on: 1vegetative growth and some chemical constituents of tomato leaves. Plant Prod., Mansoura Univ., 4 (10):1555 -1570.

DeKoning, A.N.M. (1994). Development and dry matter distribution in glasshouse tomato: a quantitative approach. Ph.D. Thesis, Wagenin-gen Agric. Univ., The Netherlands.

Dhiman, J.S., H.C. Raturi, D.S. Kachwaya and S.K. Singh (2018). Effect of nitrogen and phosphorus on tomato (Solanum lycopersicum L.) grown under polyhouse condition. Bull. Env. Pharmacol. Life Sci., 7 (1): 25-29.

Ekwu, L.G. and G.N. Nwokwu (2012). Effect of plant spacing and planting date on the growth and yield of okra. Int. J. Agric. and Rural Develop., 15 (2): 1041-1048.

El-Shafie, F.S. and S.A. El-Shikha (2003). Productivity and nutrients uptake of wheat and faba bean grown on calcerous soil as affected by water. Minufiya J. Agric. Res., 28: 1025-1048.

Gaur, A.C. and G. Sunita (1999). Phosphate solubilizing microorganisms-An overview. Current Trends in Life Sci., 23: 151-164.
Geetharani, P. and S. Parthiban (2014). Effect of organic manures on growth and seed yield of tomato. Asian J. Hort., 9 (1): 281-282.

Habibzadeh, Y. and Y. Moosavi (2014). Effect of phosphorus levels on growth of tomato plants in presence or absence of Arbuscular mycorrhizal fungi (Glomus mosseae and Glomus intraradices). Peak J. Agric. Sci., 2 (4): 51-56.

Ho, L.C. (1996). The mechanism of assimilate partitioning and carbohydrate compartmentalizeation in fruit in relation to the quality and yield of tomato. J. Exp. Bot., 47: 1239-1243.

Hossain, E.K., U. Ahamed, A.M.M. Shamsuzzaman, M. Haque and K. Nahar (2017).Yield and morph-physiological performance of different tomato varieties in winter season. Mid. East J. Sci. Res., 25 (6): 1216-1224.

Ibrahim, K.H. and O.A.S. Fadni (2013). Effect of organic fertilizers application on growth, yield and quality of tomatoes in North Kordofan (sandy soil) western Sudan. Greener J. Agri. Sci., 3 (4): 299-304.

Ilodibia, C. and M. Chukwuma (2015). Effects of application of different rates of poultry manure on the growth and yield of tomato (Lycopersicum esculentum Mill.). J. Agro., 14 (4): 251-253.

Iqbal, M., M. Niamatullah, I. Yousaf, M. Munir and M. Khan (2011). Effect of nitrogen and potassium on growth, economical yield and yield components of tomato. Sarhad J. Agric., 27 (4): 545-548.

Islam, M.A., S. Islam, A. Akter, M.H. Rahman and D. Nandwani (2017). Effect of organic and inorganic fertilizers on soil properties and the growth, yield and quality of tomato in Mymensingh, Bangladesh. Agric., 7 (3): 18.

Iwuagwu, M.O., A.A. Ukaoma and C.I. Agwu (2013). Growth and productivity of tomato (Lycopersicon esculentum Mill) following soil amendment with organic manures. ABSU J. Environ., Sci. and Technol., 3 : 447 $-456$.

Jayaweera, G.R. and D.S. Mikkelsen (1991). Assessment of ammonia volatilization from 


\section{Zagazig J. Agric. Res., Vol. 46 No. (6A) 2019}

flooded soil systems. Adv. Agron., 45 : 303353.

Kalloo, D. (1985). Tomato allied publishers private ltd. 13/14 Asaf Ali Road, New Delhi110002, 172-202.

Karanatsidis, G. and M. Berova (2009). Effect of organic-N fertilizer on growth and some physiological parameters in pepper plants (Capsicum annum L). Biotechnol. Biotechnol. Equip., 23 : 254-257.

Le, T., Z. Pék, S. Takács, A. Neményi and L. Helyes (2018). The effect of plant growthpromoting rhizobacteria on yield, water use efficiency and Brix Degree of processing tomato. Plant, Soil and Environ., 64(11): 523-529.

Lira-Saldivar, R., A. Hernandez, L. Valdez, A. Cárdenas, L. Ibarra, M. Hernández and N. Ruiz (2014). Azospirillum brasilense and Glomus intraradices co-inoculation stimulates growth and yield of cherry tomato under shadehouse conditions. Phyton-Int. J. Exp. Bot., 83: 133-138.

Mahesha, H., N. Ravichandra, B. Reddy, M. Rao and N. Gowda (2018). Studies on antagonistic activity of Bacillus spp. against nematode-bacterial wilt complex in tomato under glasshouse condition. Int. J. Curr. Microbiol. App. Sci., 7(1): 2711-2715.

Marschner, H. (1995). Mineral Nutrition of Higher Plants. $2^{\text {nd }}$ Ed., 864. Text Book. Academic Press Limited, London.

Meena, M.L., V.S. Gehlot, D.C. Meena, S. Kishor, S. Kumar and J.K. Meena (2017). Impact of biofertilizers on growth, yield and quality of tomato (Lycopersicon esculentum Mill.) cv. Pusa Sheetal. J. Pharmacognosy and Phytochem., 6 (4): 1579-1583.

Meena, R.K., K. Sanjay, M. Sutanu, K. Devendra and K. Manoj (2014). Effect of organic manures and biofertilizers on growth, flowering, yield and quality of tomato cv. Pusa Sheetal. Int. J. Agric. Sci., 10 (1): 329332.

Mehrvarz, S. and M.R. Chaich (2008). Effect of phosphate solubilizing microorganisms and phosphorus chemical fertilizer on forage and grain quality of barely (Hordeum vulgare L.). Ame. Euras. J. Agric. And Environ. Sci., 3 (6): 855-860.

Mehta, P., A. Walia, S. Kulshrestha, A. Chauhan and C.K. Shirkot (2015). Efficiency of plant growth-promoting P-solubilizing Bacillus circulans CB7 for enhancement of tomato growth under net house conditions. J. Basic Microbial., 55 (1): 33-44.

Mengel, K. and E.A. Kirkby (1978). Principles of Plant Nutrition. Eds. International Potash Institute, Berne, Switzerland, 501-508

Mesallam, M.G., N.S. Shafshak, F.A. AboSedera and M.M.A. Elmagd (2017). Effect of bio fertilizers, organic and mineral nitrogen fertilizer on growth and yield of tomato plants grown under sandy soil conditions. Ann. Agric. Sci., Moshtohor, 55 (2): 343 354.

Mfombep, P.M., B.A. Fonge, A. Atembe-afac and P.T. Tabot (2016). Soil type and amendment influence growth and yield of tomatoes (Lycopersicon esculentum L.) in the Humid Mt Cameroon Region. Int. J. Curr. Res. Biosci. Plant Biol., 3 (8): 58-64.

Mishra, M., P.S. Ranjput, A.K. Dubey, D. Singh and V. Bahadur (2016). Effect of nitrogen, phosphorus and potassium on growth, yield and quality of Tomato grown in open condition. Hort. Flora Res. Spectrum, 5 (1): 81-83.

Omar, E.S., A.A.A. Gabal, A.A. Alkharpotly, F.I. Radwan and A.I.A. Abido (2018). Effect of mineral, organic and bio-fertilization on sweet pepper (Capsicum annum L.) grown under plastic houses conditions. J. Adv. Agric. Res. (Fac. Agric. Saba Basha), 23 (3): 402-433.

Phan, T.C., M. Roel, S.S. Cong and Q. Nguyen (2002). Beneficial effects of organic amendment on improving phosphorus availability and decreasing aluminum toxicity in two upland soils. Symposium no. 13 paper no. $122617^{\text {th }}$, WCSS 14-21, Thailand.

Rahaman, M.A., M.A. Kawochar, M.M. Rahman, M.H.R. Pramanik and A.S.M.A. Hossain (2011). Growth and yield performance of 


\section{Moustafa, et al.}

tomato genotypes as influenced by phosphorus. J. Expt. Bio. Sci., 2(1): $79-84$.

Rajeev, K. and M.K. Sharma (2014). Effect of soilless growing media, biofertilizers and fertigation levels on greenhouse tomato production. Asian J. Hort., 9 (2): 408-411.

Rajeev, K., K.R.K. Sanjay, M.K. Pradeep and R. Ranjeet (2017). Effect of integrated nutrient management on growth, yield and quality of Tomato (Lycopersicon esculentum L.) cv. Pusa Ruby. Plant Archives, 17 (2): 11971200.

Ramadan, M.M.A. (2010). Effect of organic and biofertilizer on growth yield and it quality of tomato plants grow under sandy soil condition. Egypt. J. Appl. Sci., 30 (8): 496514.

Saidu, A., L.Y. Bello, E.K. Tsado and F.K. Ibrahim (2011). Effect of cow dung on the performance of tomato. Int. J. Appl. Biol. Res.

Setyamidjaja, D. (1986). Fertiizer and Fertilization. Jakarta: Simplek. 121.

Shafi, S., M. Asif, M. Zargar, S.T. Maqbool, S.A. Mir, Z.A. Baba, Z.M. Dar and S. Ayman (2019). Impact of microbial inoculants on growth and yield of tomato (Solanum lycopersicon L.) under temperate conditions. J. Pharmacognosy and Phytochem., 8 (1): 1261-1264.

Shobha, G. and B.S. Kumudini (2012). Antagonistic effect of the newly isolated PGPR Bacillus spp. on Fusarium oxysporum. Int. J. App. Sci. and Eng. Res., 1 (3): 463474.

Shukla, Y.R., A.K. Thakur and A. Joshi (2009). Effect of inorganic and bio-fertilizers on yield and horticultural traits in tomato. Indian J. Hort., 66 (2): 285-287.

Sivakumar, R. and S. Srividhya (2016). Impact of drought on flowering, yield and quality parameters in diverse genotypes of tomato (Solanum lycopersicum L.). Adv. Hort. Sci., 30 (1): 3-11.

Snedecor, G.W. and W.G. Cochran (1980). Statistical Methods. $7^{\text {th }}$ Ed.. Iowa State Univ. Press, Ames. Iowa, USA.

Subba, R.N.S. (1999). Soil Microbiology. (Fourth edition of soil microorganisms and plant growth). Sci. Publishers, Inc. USA, 4755.

Shamsuzzaman, B., H.B. Lingaiah, M. Shivapriya and H.B. Pavithra (2017). Evaluation of tomato genotypes for growth, yield and quality attributes under eastern dry zone of Karnataka, India. Int. J. Curr. Microbiol. App. Sci., 6 (11): 1922-1930.

Tiamiyu, R. A., H. G. Ahmed and A. S. Muhammad (2012). Effect of sources of organic manure on growth and yields of okra (Abelmoschus esculentus L.) in Sokoto, Nigeria. Nigerian J. Basic and App. Sci., 20 (3): 213-216.

Tisdale, S.L., W.L. Nelson, J.D. Beaton and J.L. Havlin. (2003). Soil Fertility and Fertilizers. $5^{\text {th }}$ Ed., Prentice-Hall of India, New Delhi, India.

Wani, S. A., S. Chand and T. Ali (2013). Potential use of Azotobacter chroococcum in crop production: an overview. Current Agric. Res. J., 1(1): 35-38.

Zdor, R.E. and A.J. Anderson (1992). Influence of root colonizing bacteria on the defense response of bean. Plant and Soil, 140: 99-107. 
Zagazig J. Agric. Res., Vol. 46 No. (6A) 2019

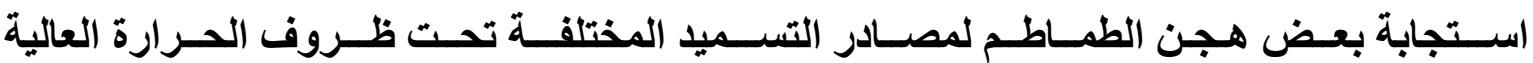

\author{
أحمد على مصطفى - محسن حسن السواح - محمد حامد عريشة \\ قسم البساتين ـ كلية الزر اعة - جامعة الزقازيق ـ مصر
}

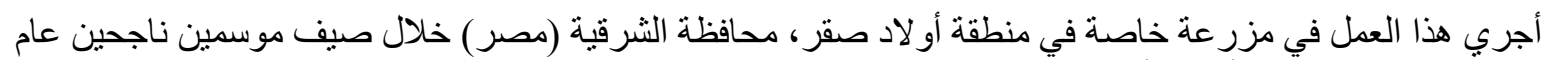

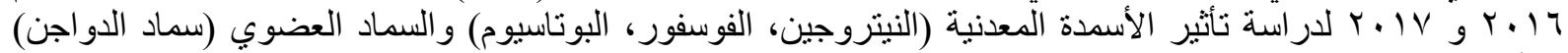

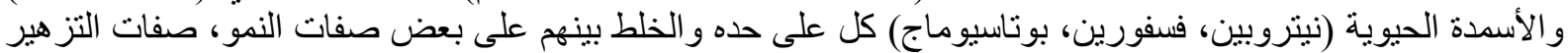

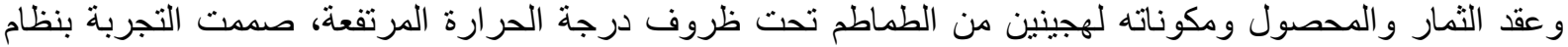

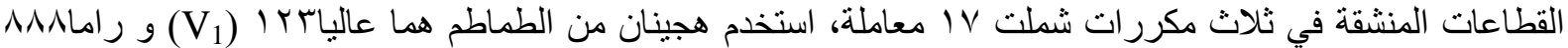

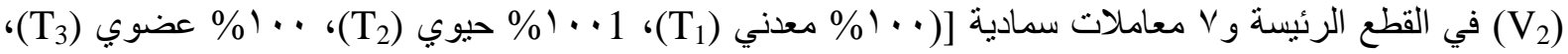

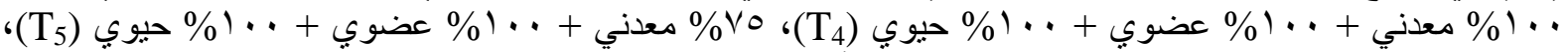

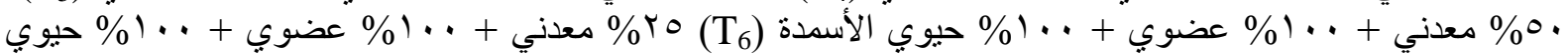

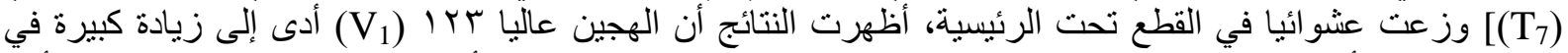

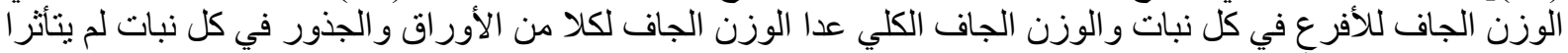

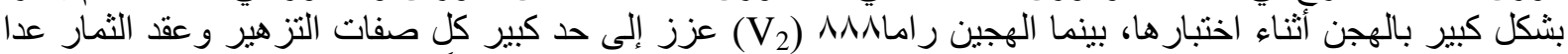

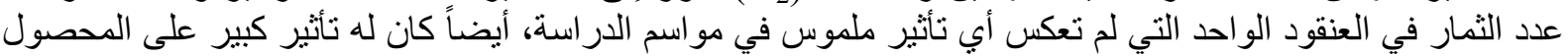

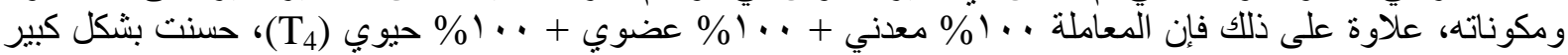

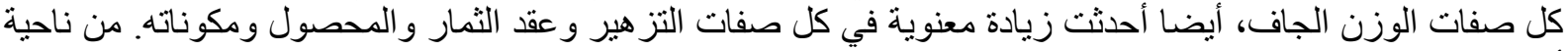

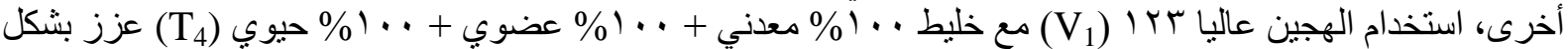

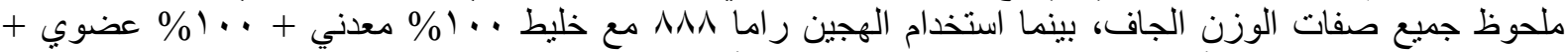

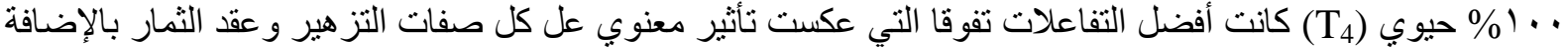

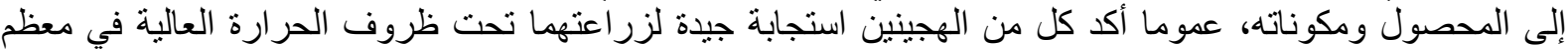
الصفات 